„Ante Portas - Studia nad Bezpieczeństwem”

2019, $\mathrm{Nr} 1(12)$

DOI: $10.33674 / 220196$

Michał HARKOT ${ }^{1}$

Polska

\title{
ODSTRASZANIE JAKO ELEMENT STRATEGII BEZPIECZEŃSTWA IZRAELA
}

\begin{abstract}
Abstrakt:
Położenie geopolityczne Izraela $w$ regionie Bliskiego Wschodu posiada nad wyraz niekorzystny charakter. W rezultacie, izraelscy decydenci zmuszeni zostali do wypracowania rozbudowanych mechanizmów reagowania na rzeczywiste czy też potencjalne zagrożenia. Obecnie jednym $z$ takich mechanizmów sa działania ukierunkowane na odstraszanie. Należy zauważyć, $\dot{z} e$ w odniesieniu do polityki bezpieczeństwa Izraela, na przestrzeni ostatnich lat to wtaśnie inicjatywy zwiazane z zapobieganiem zaczęty odgrywać decydujaca rolę. Zgodnie z izraelska strategia bezpieczeństwa, odstraszanie należy utożsamiać z trzema elementami: wiarygodna groźba przeprowadzenia przez Izrael ofensywnych dziatań odwetowych, rozbudowa sit zbrojnych oraz dążeniem do ograniczenia zasobów oraz możliwości rozwoju ugrupowań wrogo nastawionych do Izraela. Uwzględniając bieżace wydarzenia polityczne na Bliskim Wschodzie, postaram się tym samym wykazać istotę izraelskiej doktryny odstraszania.
\end{abstract}

Stowa kluczowe:

Izrael, Bliski Wschód, odstraszanie, polityka bezpieczeństwa

\section{Abstract:}

The geopolitical location of Israel in the Middle East region is extremely unfavorable. As a result, Israeli policymakers were forced to develop a comprehensive mechanism of responding in relation to real or potential threats. Currently, one of these mechanisms is focused on deterring. It should be noted that in the context of Israeli security policy, in recent years initiatives devoted to prevention have started to play a decisive role. According to the

\footnotetext{
${ }^{1}$ Michał Harkot, doktorant na kierunku nauki o polityce na Uniwersytecie Marii CurieSkłodowskiej w Lublinie. Email: harkot.michal92@gmail.com
} 
Israeli security strategy, deterrence should be connected with three elements: a credible threat of conducting by Israel forces offensive retaliatory actions, the extension of armed forces and seeking to reduce resources and development opportunities in the context of groups hostile to Israel. Taking into account current political events in the Middle East, I will try to point out the essence of the Israeli deterrence doctrine.

\section{Keywords:}

Israel, the Middle East, deterrence, security policy

\section{Wstęp}

Przedmiotem niniejszego artykułu jest charakterystyka polityki odstraszania $\mathrm{w}$ ramach izraelskiej strategii bezpieczeństwa. Zaproponowana tematyka posiada nie tylko walor deskryptywny, ale przede wszystkim eksplanacyjny, albowiem pozwala ona zrozumieć tendencje związane $\mathrm{z}$ obecnym kształtem izraelskiej polityki bezpieczeństwa. Zastosowane $\mathrm{w}$ artykule ramy czasowe odnoszą się do okresu po 2010 roku, w nawiązaniu do wybuchu masowych protestów społecznych na Bliskim Wschodzie (tzw. arabska wiosna), które w konsekwencji wymusiły na Izraelu redefinicję bieżących wyzwań oraz zagrożeń2 ${ }^{2}$. Ramy przestrzenne pokrywają się zaś z granicami regionu Bliskiego Wschodu, bowiem jak zostanie wykazane $\mathrm{w}$ dalszej części, to właśnie na tym obszarze izraelscy decydenci dokonali identyfikacji głównych zagrożeń bezpieczeństwa.

W artykule podjęto próbę odpowiedzi na następujące pytania badawcze. Po pierwsze, co jest istotą izraelskiej polityki odstraszania? Po drugie, dlaczego po raz pierwszy w historii upubliczniono treść Strategii Sił Obronnych Izraela? Po trzecie, w jaki sposób aktualna Strategia Sił Obronnych Izraela wpływa na kształt polityki odstraszania? Po czwarte, w jakim kierunku ewoluuje strategia bezpieczeństwa Izraela?

$\mathrm{Na}$ podstawie postawionych pytań badawczych, weryfikacji poddano cztery hipotezy. Po pierwsze, w wyniku obecnych wyzwań oraz zagrożeń, istota izraelskiej polityki odstraszania zawiera się w trzech komponentach: wiarygodnej groźbie ofensywnych działań odwetowych, rozbudowie sił zbrojnych oraz ograniczaniu zasobów i możliwości rozwoju wrogich ugrupowań. Po drugie, Strategia Sił Obronnych Izraela została upubliczniona pierwszy raz w historii z dwóch powodów: obecności nowych zagrożeń, jak również w celu jasnego zadeklarowania regionalnym przeciwnikom Izraela o obowiązujących „regułach gry”, których nieprzestrzeganie automatycznie wiązać ma się ze

\footnotetext{
2 Vide: A. Dzisiów-Szuszczykiewicz, ,,Trzęsienie ziemi” $w$ środowisku bezpieczeństwa Izraela, „Bezpieczeństwo Narodowe” 2011, nr 19, III.
} 
zdecydowaną reakcją. Po trzecie, autorzy Strategii Sił Obronnych Izraela w wyniku akcentowania konieczności zwiększania nakładów finansowych na rzecz armii, zwracają równocześnie uwagę na rozwój polityki odstraszania. Po czwarte, w rezultacie aktualnych wyzwań oraz zagrożeń, strategia bezpieczeństwa Izraela ewoluuje od dominującej roli środków wojskowych (twardych), w kierunku środków niewojskowych (miękkich).

W artykule wykorzystano dwa rodzaje metod badawczych. Po pierwsze, badania ilościowe, które zilustrowały nakłady finansowe państw Bliskiego Wschodu w latach 2010-2018 na rzecz armii (potencjał militarny jako filar polityki odstraszania). Po drugie zaś, badania jakościowe w postaci analizy przypadku (case study). W związku z powyższym charakterystyce poddano wydarzenia zapoczątkowane 30 marca 2018 roku, dotyczące masowych demonstracji ludności palestyńskiej wzdłuż granicy pomiędzy Izraelem a Strefą Gazy (ograniczone działania ofensywne w ramach akcji odwetowej jako kolejny filar polityki odstraszania).

Struktura artykułu obejmuje wstęp, rozwinięcie składające się z trzech elementów (zarys strategii bezpieczeństwa Izraela, polityka odstraszania ujęcie teoretyczne, polityka odstraszania - ujęcie praktyczne) oraz zakończenie. Najważniejszym źródłem pierwotnym przeprowadzonych badań jest Strategia Sił Obronnych Izraela, w której autorzy zilustrowali kształt izraelskiej polityki odstraszania. Istotna okazała się również analiza Stockholm International Peace Research Institute (SIPRI), która przedstawiła dane dotyczące nakładów finansowych państw Bliskiego Wschodu na rzecz armii. W artykule posłużono się również publikacjami poszczególnych think-tanków.

\section{Zarys strategii bezpieczeństwa Izraela}

Aktualna strategia bezpieczeństwa Izraela opiera się na kilku niezmiennych fundamentach, gdzie do najważniejszych należą: wczesne ostrzeganie (early warning), rozstrzygające uderzenie (decisive victory) oraz odstraszanie (deterrence) ${ }^{3}$. W niniejszym artykule uwaga skupiona została przede wszystkim na ostatnim z wymienionych elementów, a więc na polityce mającej na celu zniechęcenie przed potencjalnym atakiem. Najprościej, istotę odstraszania można zdefiniować jako dążenie do utrzymywania rozbudowanych sił zbrojnych, zdolnych do pokonania wroga w sposób, który generuje jak najmniejsze straty własne ${ }^{4}$.

\footnotetext{
${ }^{3}$ E. Lerman, Reasserting Israel's Deterrence in Gaza, The Jerusalem Institute for Strategy and Security, 11.12.2018, <https://jiss.org.il/en/lerman-reasserting-israels-deterrence-ingaza/> (15.04.2019).

4 J. M. Newhard, A Strategic Doctrine of Disproportionate Force For Decentralized Asymmetric Warfare, "Libertarian Papers" 2018, Vol. 10, No. 2, <http:/libertarianpapers.org/ wp-content/uploads/2018/09/post/2018/09/lp-10-2-3.pdf> (15.04.2019).
} 
Kształt tego typu działań zilustrowano w oficjalnej Strategii Sił Obronnych Izraela (Strategy of the Israel Defense Forces), opublikowanej przez Szefa Sztabu Generalnego, generała Gadi'ego Eizenkota w sierpniu 2015 roku (co znamienne, dokument tej rangi został przedstawiony publicznie po raz pierwszy w historii Izraela). Na wstępie należy wyjaśnić, z jakich powodów izraelska armia podjęła decyzję o publikacji tego typu tekstu. Po pierwsze, była to reakcja na zmiany zachodzące $\mathrm{w}$ regionie Bliskiego Wschodu. Nowe rodzaje zagrożeń o charakterze asymetrycznym, niekontrolowany dostęp do nowoczesnego uzbrojenia czy też postępująca zależność od sprawnych systemów informatycznych, wymusiły na Izraelu redefinicję dotychczasowego kształtu polityki bezpieczeństwa. W związku $\mathrm{z}$ powyższym za racjonalne uznano pierwszeństwo działań o charakterze defensywnym, prewencyjnym i w jak najmniejszym stopniu angażujących izraelskie wojsko ${ }^{5}$. Po drugie zaś, publikacja oficjalnej Strategii Sił Obronnych Izraela to swoista forma komunikatu skierowanego do nieprzyjaciół, w którym zawarto jasno sprecyzowane „reguły gry” oraz konsekwencje ich nieprzestrzegania. Jak zostanie wykazane w dalszej części artykułu, tego typu klarowność w przekazie stanowi obecnie jedną z podstaw skutecznej polityki odstraszania.

Struktura omawianej strategii obejmuje wstęp, pięć rozdziałów oraz konkluzję. W rozdziale pierwszym przedstawiono podstawowe zadania izraelskiej armii, do których należą przetrwanie państwowości, zapewnienie integralności terytorialnej, ochrona ludności cywilnej, utrzymanie żydowskiego charakteru państwa, umacnianie demokratycznych wartości, ochrona społeczno-gospodarczej stabilności oraz wzrost międzynarodowej pozycji Izraela. W dalszej części rozdziału zilustrowano też największe zagrożenia, zaliczając do nich: państwa (Iran, Liban), państwa upadłe (Syria), organizacje subpaństwowe (Hezbollah, Hamas), jak również organizacje terrorystyczne („Państwo Islamskie”, Islamski Dżihad czy też Palestyński Islamski Dżihad). W rozdziale drugim wskazano na najistotniejsze procesy polityczne o charakterze wewnętrznym, jak też zewnętrznym. Do tych pierwszych zaliczono dążenie izraelskiej klasy politycznej do pokojowego rozstrzygania sporów oraz nacisk na społeczno-gospodarczy rozwój, nawet kosztem inwestycji na rzecz wojska. Procesy o charakterze zewnętrznym odnosiły się przede wszystkim do aspiracji islamskich ugrupowań w kierunku redefinicji aktualnego statusu quo, a więc narzucenia islamskiego panowania w całym regionie bliskowschodnim. W rozdziale trzecim zilustrowano zasady, stojące u podstaw właściwego funkcjonowania izraelskiej armii, a więc prymat działań o

5 Deterring Terror. How Israel Confronts the Next Generation of Threats. English Translation of the Official Strategy of the Israel Defense Forces, "Belfer Center Special Report" August 2016, s. 4, <https://www.belfercenter.org/sites/default/files/files/publication/ IDF\%20doctrine\%20translation\%20-\%20web\%20final2.pdf> (15.04.2019). 
charakterze defensywnym, prewencyjnym oraz odstraszającym. Rozdział czwarty dotyczył izraelskich struktur wojskowych. Największe kompetencje przypisano Sztabowi Generalnemu oraz szefowi tegoż organu, wskazując jednocześnie na konieczność zwiększenia współpracy $z$ instytucjami o charakterze cywilnym, takimi jak Ministerstwo Spraw Zagranicznych, Ministerstwo Sprawiedliwości czy Gabinet Prezesa Rady Ministrów. W rozdziale piątym przedstawiono zaś niezbędne kierunki rozwoju i modernizacji izraelskich struktur wojskowych, odwołując się przede wszystkim do systemu szkoleń i rekrutacji, technologii, ćwiczeń wojskowych oraz sprawności procesu decyzyjnego ${ }^{6}$.

\section{Polityka odstraszania - ujęcie teoretyczne}

Istota izraelskiej polityki odstraszania oparta została $\mathrm{w}$ pierwszej kolejności na samym potencjale wojskowym tego państwa. Dążenie do ilościowej oraz jakościowej przewagi militarnej nad pozostałymi państwami regionu Bliskiego Wschodu ma na celu zniechęcenie przeciwnika przed dokonaniem potencjalnego ataku na Izrael (ze względu na małe szanse powodzenia tego typu przedsięwzięcia, jak również możliwość zwielokrotnionej akcji odwetowej). Warto jednak zaznaczyć, że ze względu na nowe zagrożenia, dominująca pozycja militarna $\mathrm{w}$ regionie nie stanowi już tak silnego filaru bezpieczeństwa jak chociażby $\mathrm{w}$ okresie zimnowojennym ${ }^{7}$. Wzrost zagrożeń o charakterze asymetrycznym znacznie ogranicza bowiem skuteczną odpowiedź na atak poprzez wykorzystanie regularnej armii. Izraelscy decydenci za najbardziej adekwatną i skuteczną metodę uznali więc zniechęcanie i odstraszanie wrogo nastawionych ugrupowań. Były szef izraelskiego wywiadu wojskowego Amos Yadlin stwierdził wprost, że nie jest możliwe całkowite wyeliminowanie potencjału Hezbollahu oraz Hamasu, jednak wykonalnym jest już skuteczne odstraszenie tych organizacji przed potencjalnym atakiem. Yadlin wskazał $\mathrm{w}$ tym miejscu na dwa podstawowe elementy, ściśle ze sobą korelujące. Po pierwsze, na zdecydowane akcje odwetowe, po drugie zaś na semi-państwowy charakter Hamasu oraz Hezbollahu. W momencie kiedy przedstawiciele tych organizacji zaczęli być odpowiedzialni za gospodarkę, szkolnictwo oraz szeroko pojęte życie społeczne, wykorzystywanie przemocy oraz terroru jako środków polityki zagranicznej, przestało być w ich oczach tak ,atrakcyjnym” kierunkiem działań. Świadomość odpowiedzialności za życie własnych obywateli wymusiła na Hamasie oraz Hezbollahu prowadzenie zdecydowanie bardziej

\footnotetext{
${ }^{6}$ Ibidem, s. 1-49.

${ }^{7}$ Ibidem, s. 24.
} 
racjonalnej polityki zagranicznej ${ }^{8}$. W obliczu powyższych uwarunkowań, realizowanie przez Izrael skutecznej strategii odstraszania wydaje się być jak najbardziej uzasadnionym kierunkiem działania.

Kolejnym elementem charakterystycznym dla izraelskiej strategii odstraszania jest uwzględnianie indywidualnej specyfiki każdego przeciwnika, przede wszystkim $\mathrm{w}$ oparciu o bieżącą analizę dostępnych informacji dotyczących uwarunkowań, posiadanego potencjału, tożsamości czy chociażby mechanizmów związanych z samym procesem decyzyjnym nieprzyjaciela.

Co ciekawe, w treści Strategii Sił Obronnych Izraela znajduje się rozróżnienie na dwa rodzaje odstraszania. Pierwszym z nich jest tzw. ogólne odstraszanie, które związane jest $\mathrm{z}$ utrzymywaniem militarnej supremacji w regionie Bliskiego Wschodu, a co za tym idzie - budowaniem reputacji oraz swego rodzaju szacunku. Drugi zaś to tzw. szczegółowe odstraszanie, dotyczące konkretnego zagrożenia oraz konieczności podjęcia odpowiednich działań ${ }^{9}$.

W związku z powyższym, Strategia Sił Obronnych Izraela wskazuje na trzy komponenty odstraszania. Po pierwsze, na wiarygodną groźbę przeprowadzenia przez Izrael ofensywnych działań odwetowych. Ten filar oparty jest zaś na: rozbudowie sił zbrojnych (częściowo widocznych dla przeciwnika w celu uwypuklenia gotowości do działania), utrwalaniu wizerunku państwa, które jest w stanie podejmować ryzyko oraz ograniczonych działaniach ofensywnych (limited offensive actions), realizowanych w sytuacji wrogich poczynań przeciwnika. Po drugie, na rozbudowę sił zbrojnych, co ma na celu przekonanie potencjalnego agresora o bezsensowności prowadzenia działań ofensywnych z powodu militarnej dysproporcji na korzyść Izraela. Po trzecie zaś, na dążenie do ograniczania zasobów oraz możliwości rozwoju ugrupowań wrogo nastawionych do Izraela ${ }^{10}$.

Wskazuje się, że chcąc osiągnąć maksymalną efektywność, polityka odstraszania powinna cechować się przejrzystością, właściwym potencjałem oraz wiarygodnością. Przejrzystość związana jest z wyznaczeniem „,czerwonej linii”, której przekroczenie automatycznie skutkować ma akcją odwetową ze strony Izraela. Ważnym elementem jest to, aby komunikat wystosowany był w odpowiednim języku, formie oraz miejscu, celem skutecznego przekazania ostrzeżenia. Odpowiedni potencjał związany jest ze zdolnością do ponoszenia kosztów, które niejednokrotnie mogą przewyższać pożądane korzyści.

\footnotetext{
${ }^{8}$ G. Allison, Why ISIS Fears Israel, Belfer Center for Science and International Affairs, 8.08.2016, $<$ https://www.belfercenter.org/index.php/publication/why-isis-fears-israel> (18.04.2019).

${ }^{9}$ Deterring Terror. How Israel ..., s. 24.

${ }^{10}$ Ibidem, s. 24-25.
} 
Natomiast wiarygodność dotyczy gotowości do ponoszenia wspomnianych kosztów ${ }^{11}$.

\section{Polityka odstraszania - ujęcie praktyczne}

Chcąc zilustrować dążenie Izraela do militarnej supremacji w regionie, a w konsekwencji - do rozwoju skutecznej polityki odstraszania, można posłużyć się bazą danych sporządzoną przez SIPRI, który dokonał zestawienia wydatków wojskowych współczesnych państw. Do celów artykułu wykorzystano dane odnoszące się do państw Bliskiego Wschodu, a więc regionu, w granicach którego Izrael identyfikuje obecnie największe zagrożenia dla swojego bezpieczeństwa.

Zgodnie z informacjami zawartymi w Tabeli 1, państwem o największym wskaźniku wydatków o charakterze wojskowym w roku 2018 była Arabia Saudyjska $(65,84$ mld \$) oraz Turcja $(22,09$ mld \$). Izrael w tym zestawieniu znajduje się na miejscu trzecim $(15,69$ mld \$). Jednak warto zwrócić uwagę na fakt, że zarówno Arabia Saudyjska, jak i Turcja nie zagrażają Państwu Izrael w sposób bezpośredni. Posiłkując się Strategią Sił Obronnych Izraela, do największych zagrożeń należą bowiem: państwa odległe (Iran), państwa sąsiedzkie (Liban), państwa upadłe (Syria), organizacje subpaństwowe (Hamas, Hezbollah) oraz ugrupowania o charakterze terrorystycznym (na przykład „Państwo Islamskie”) ${ }^{12}$. Odnosząc się do wymienionych podmiotów, Izrael zdecydowanie przewyższa je pod kątem potencjału militarnego, dążąc tym samym do realizacji skutecznej polityki odstraszania, opartej na wojskowej supremacji w regionie. Warto również w tym miejscu przytoczyć dane zawarte w Tabeli 2, gdzie przedstawione zostały wydatki na zbrojenia przypadające na jednego mieszkańca w regionie Bliskiego Wschodu w 2017 roku. Izrael Z wartością 1788 \$ uplasował się na drugim miejscu, ustępując jedynie Arabii Saudyjskiej (2 137 \$). Powyższe zestawienie w jeszcze większym stopniu wskazało zatem na militarny potencjał Izraela.

Co więcej, treść Strategii Sił Obronnych Izraela wskazuje z jednej strony na konieczność dalszej modernizacji armii oraz doskonalenia systemu szkoleniowego, z drugiej zaś uwypukla mnogość i różnorodność współczesnych zagrożeń. Należy zatem przypuszczać, że treść opublikowanego dokumentu skłonić ma izraelskie społeczeństwo, a w konsekwencji izraelskich decydentów do zwiększenia nakładów finansowych na rzecz armii. W niniejszej strategii można odnaleźć nawet zawoalowany zarzut odnoszący się do przeznaczania

\footnotetext{
${ }^{11}$ G. Allison, Why ISIS Fears...

${ }^{12}$ Deterring Terror. How Israel..., s. 4.
} 
przez izraelskie władze coraz większych środków na społeczno-gospodarczy rozwój kosztem pozycji militarnej ${ }^{13}$.

Tabela 1: Wydatki na zbrojenia w latach 2010-2018 na Bliskim Wschodzie (mln \$).

\begin{tabular}{|l|l|l|l|l|l|l|l|l|l|}
\hline & $\mathbf{2 0 1 0}$ & $\mathbf{2 0 1 1}$ & $\mathbf{2 0 1 2}$ & $\mathbf{2 0 1 3}$ & $\mathbf{2 0 1 4}$ & $\mathbf{2 0 1 5}$ & $\mathbf{2 0 1 6}$ & $\mathbf{2 0 1 7}$ & $\mathbf{2 0 1 8}$ \\
\hline $\begin{array}{l}\text { Arabia } \\
\text { Saudyjska }\end{array}$ & 53396 & 54122 & 61251 & 70194 & 82732 & 88233 & 63141 & 70400 & 65843 \\
\hline Bahrajn & 971 & 1195 & 1331 & 1468 & 1566 & 1503 & 1526 & 1533 & 1357 \\
\hline Egipt & 3209 & 3117 & 3033 & 3008 & 3281 & 3479 & 3277 & 2766 & 2564 \\
\hline Irak & 4427 & 4771 & 4338 & 7999 & 6963 & 9536 & 5971 & 7416 & 6200 \\
\hline Iran & 14204 & 12809 & 13497 & 10661 & 10574 & 11123 & 12604 & 13931 & 12612 \\
\hline Izrael & 16062 & 16625 & 16778 & 17213 & 18119 & 18174 & 15740 & 15582 & 15690 \\
\hline Jemen & 2847 & 2581 & 2365 & 2176 & 2093 & b.d. & b.d. & b.d. & b.d. \\
\hline Jordania & 1859 & 1827 & 1614 & 1511 & 1574 & 1656 & 1827 & 1940 & 1874 \\
\hline Katar & 2174 & b.d. & b.d. & b.d. & b.d. & b.d. & b.d. & b.d. & b.d. \\
\hline Kuwejt & 5100 & 5827 & 6306 & 5966 & 5955 & 5998 & 6559 & 6765 & 7211 \\
\hline Liban & 1863 & 1821 & 1846 & 1940 & 2234 & 2289 & 2686 & 2441 & 2606 \\
\hline Oman & 4126 & 5402 & 9706 & 9103 & 8443 & 7739 & 8063 & 6803 & 6611 \\
\hline Syria & b.d. & b.d. & b.d. & b.d. & b.d. & b.d. & b.d. & b.d. & b.d. \\
\hline Turcja & 13087 & 13214 & 13504 & 13838 & 13917 & 14355 & 16630 & 17824 & 22088 \\
\hline ZEA & 19885 & 21600 & 21282 & 26070 & 24601 & b.d. & b.d. & b.d. & b.d. \\
\hline
\end{tabular}

Źródło: SIPRI, Data for all countries from 1988-2018 in constant (2017) USD, $<$ https://www.sipri.org/databases/milex> (22.04.2019).

Tabela 2: Wydatki na zbrojenia przypadające na jednego mieszkańca $w$ regionie Bliskiego Wschodu w 2017 roku.

\begin{tabular}{|l|l|l|l|}
\hline & $\begin{array}{l}\text { Wydatki na } \\
\text { zbrojenia (mIn \$) }\end{array}$ & Liczba ludności ${ }^{\mathbf{1 4}}$ & $\begin{array}{l}\text { Wydatki na } \\
\text { zbrojenia } \\
\text { przypadające na } \\
\text { 1 mieszkańca (\$) }\end{array}$ \\
\hline $\begin{array}{l}\text { Arabia } \\
\text { Saudyjska }\end{array}$ & 70400 & 32938210 & 2137 \\
\hline Bahrajn & 1533 & 1492580 & 1027 \\
\hline Egipt & 2766 & 97553150 & 28 \\
\hline
\end{tabular}

\footnotetext{
${ }^{13}$ Ibidem, s. 8.

14 The World Bank, Population, total, <https://data.worldbank.org/indicator/sp.pop.totl> (10.05.2019).
} 


\begin{tabular}{|l|l|l|l|}
\hline Irak & 7416 & 38274620 & 194 \\
\hline Iran & 13931 & 81162790 & 172 \\
\hline Izrael & 15582 & 8713300 & 1788 \\
\hline Jemen & b.d. & 28250420 & b.d. \\
\hline Jordania & 1940 & 9702350 & 200 \\
\hline Katar & b.d. & 2639210 & b.d. \\
\hline Kuwejt & 6765 & 4136530 & 1635 \\
\hline Liban & 2441 & 6082360 & 401 \\
\hline Oman & 6803 & 4636260 & 1467 \\
\hline Syria & b.d. & 18269870 & b.d. \\
\hline Turcja & 17824 & 80745020 & 221 \\
\hline ZEA & b.d. & 9400150 & b.d. \\
\hline
\end{tabular}

Opracowanie własne.

Po zilustrowaniu polityki opartej na militarnej dominacji w regionie, $w$ tej części artykułu analizie poddany zostanie kolejny komponent odstraszania, związany tym razem z wiarygodną groźbą ofensywnych działań odwetowych. Dla pełnego scharakteryzowania niniejszego punktu analizie poddane zostaną gwałtowne protesty ludności palestyńskiej w Strefie Gazy na przełomie marca i kwietnia 2018 roku. Demonstracja zorganizowana pod hasłem „Wielkiego Marszu Powrotu" ${ }^{15}$, zapoczątkowana została dokładnie 30 marca. Około 40 tysięcy protestujących rozlokowało się w wybranych punktach granicznych pomiędzy Strefą Gazy a Izraelem. Głównym motywem demonstrantów był sprzeciw wobec trwającej od kilku dekad polityki wysiedleńczej oraz społecznej marginalizacji. Uczestnicy pojmowali swój pochód jako demonstrację o charakterze pokojowym, jednak strona izraelska odebrała zorganizowany protest jako polityczno-militarne zagrożenie, mogące zostać wykorzystane przez członków Hamasu. Istniały poważne obawy, że aktywiści mogą ukryć się wśród nieuzbrojonych demonstrantów i w odpowiednim momencie zaatakować pogranicznych żołnierzy, umożliwiając w ten sposób

\footnotetext{
${ }^{15}$ Wielki Marsz Powrotu (ang. Great March of Return) - kilkumiesięczne demonstracje ludności palestyńskiej w Strefie Gazy. Głównym postulatem protestujących było przyznanie prawa powrotu do ziem, z których zostali wysiedleni w związku z wieloletnią polityką Izraela. Palestyńczycy sprzeciwili się również blokadzie Strefy Gazy oraz przeniesieniu przez Stany Zjednoczone swojej ambasady z Tel Awiwu do Jerozolimy. Data rozpoczęcia marszu nawiązuje do wydarzeń z 30.03.1976 roku, kiedy ludność palestyńska po raz pierwszy w sposób masowy zaprotestowała przeciwko ogłoszonemu przez Izrael planowi wywłaszczenia znacznych obszarów ziemskich znajdujących się pod kontrolą palestyńską. Współcześnie 30 marca uznawany jest wśród Palestyńczyków za święto o charakterze narodowym.
} 
sforsowanie izraelskiej granicy ${ }^{16}$. W rezultacie zaostrzającej się sytuacji, izraelska armia użyła gazu łzawiącego, pocisków niepenetracyjnych, a ostatecznie ostrej amunicji. W wyniku starć śmierć poniosło ponad 130 Palestyńczyków ${ }^{17}$. Poniższy wykres ilustruje skalę demonstracji oraz liczbę ofiar w okresie pomiędzy lutym a czerwcem 2018 roku.

Wykres 1: Skala palestyńskich demonstracji oraz liczba ofiar (luty-czerwiec 2018 rok).

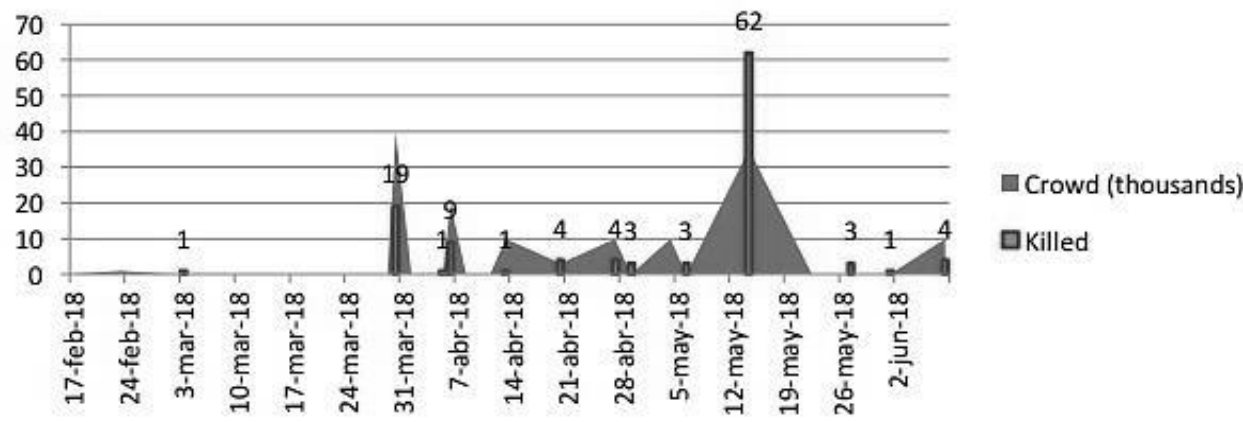

Źródło: A. Orion, The Gaza Spring Offensive: Hamas Hybrid Warfare Threat and Israel's Response, s.

<http://www.friendsofisraelinitiative.org/contents/uploads/papers/pdf/FOI_ Paper48.pdf > (22.04.2019).

Zestawione dane wskazują wyraźnie na fakt, że w sytuacji rosnącej skali protestów, zaostrzona reakcja ze strony izraelskiej armii w krótkiej perspektywie czasu hamowała determinację demonstrantów, a tym samym rozmiar pochodów. Do najważniejszych założeń izraelskiej polityki odstraszania w kontekście scharakteryzowanych demonstracji zaliczono: utrzymanie względnego porządku publicznego, osłabienie politycznej pozycji Hamasu oraz odstraszenie przed wznowieniem ataków skierowanych w Izrael, przy jednoczesnym uniknięciu działań wojennych i ponownej okupacji Strefy Gazy ${ }^{18}$.

Należy ocenić, że przyjęte założenia w znacznym stopniu zostały zrealizowane. W wyniku przeprowadzonych akcji odwetowych, w przeciągu kilku miesięcy poziom społecznych protestów na pograniczu palestyńskoizraelskim został zredukowany do zera. Jednak z powodu liczby ofiar,

\footnotetext{
${ }^{16}$ A. Orion, The Gaza Spring Offensive: Hamas Hybrid Warfare Threat and Israel's Response, Friends of Israel Initiative, 29.06.2018, <http://www.friendsofisraelinitiative.org/ contents/uploads/papers/pdf/FOI_Paper48.pdf> (22.04.2019).

${ }^{17}$ Ibidem, s. 1.

${ }^{18}$ Ibidem, s. 8.
} 
wydarzenia te odbiły się szerokim echem wśród światowej opinii publicznej, co również wśród samych izraelskich decydentów wywołało szereg dyskusji na temat podjętych przez armię środków oraz metod. Według emerytowanego generała izraelskiej armii Shlomo Broma, celem Palestyńczyków było przede wszystkim zwrócenie uwagi światowej opinii publicznej na problemy mieszkańców Strefy Gazy. Gwałtowna i bezkompromisowa reakcja Izraela pozwoliła $\mathrm{w}$ ten sposób na ponowne podniesienie kwestii palestyńskiej do rangi debaty o charakterze międzynarodowym ${ }^{19}$. Brom zaznaczył, że w przypadku zminimalizowania przemocy ze strony Izraela, demonstracje zostałyby załagodzone o wiele sprawniej ${ }^{20}$. Nie zmienia to jednak faktu, że zastosowana przez Izrael polityka odstraszania, oparta na ofensywnych działaniach odwetowych przyniosła oczekiwane rezultaty, tzn. zneutralizowała palestyńskie protesty, zniechęciła Hamas do dalszych ataków oraz zapobiegła eskalacji konfliktu.

\section{Zakończenie}

W artykule dokonano ilustracji izraelskiej polityki odstraszania, zarówno od strony teoretycznej, jak też praktycznej. Należy stwierdzić, że w wyniku wzrostu zagrożeń o charakterze asymetrycznym, „miękkie” środki polityki bezpieczeństwa, do których z pewnością zaliczyć można działalność na rzecz odstraszania, w kontekście izraelskiej polityki bezpieczeństwa zaczynają odgrywać dominującą rolę. Warto też zauważyć, że dopiero gdy działania ukierunkowane na wczesne ostrzeganie bądź odstraszanie okażą się nieskuteczne, izraelscy decydenci dążą do rozstrzygnięcia konfliktu w sposób siłowy. Co więcej, znaczenie opinii publicznej oraz rola prawa międzynarodowego również wymusza na Izraelu uwzględnianie mniej konfrontacyjnych metod reagowania. Należy zatem skonstatować, że strategia odstraszania stanowi obecnie racjonalny kierunek $\mathrm{w}$ relacjach $\mathrm{z}$ potencjalnymi bądź rzeczywistymi przeciwnikami Izraela.

${ }^{19}$ Sytuacja w Strefie Gazy była szeroko komentowana na forum międzynarodowym. Sekretarz generalny ONZ Antonio Guterres zaapelował o powstrzymanie działań militarnych oraz wezwał do przeprowadzenia śledztwa. Prezydent Turcji określił izraelską odpowiedź na demonstracje „,niehumanitarnym atakiem”, zaś samego premiera Benjamina Netanjahu ,terrorystą”. Sytuacja w Strefie Gazy była również relacjonowana w międzynarodowych mediach i prasie, na przykład w BBC, CNN, The Guardian, New York Times, The Washington Post, Reuters czy Al Jazeera.

${ }^{20}$ I. Kershner, After Gaza Clash, Israel and Palestinians Fight With Video and Words, "The New York Times", 1.04.2018, <https://www.nytimes.com/2018/04/01/world/middleeast/israelgaza-fighting.html?moduleinline> (25.04.2019). 


\section{BIBLIOGRAFIA:}

$\checkmark$ Allison G., Why ISIS Fears Israel, Belfer Center for Science and International Affairs, 8.08.2016, $<$ https://www.belfercenter.org/index.php/publication/why-isis-fearsisrael>

$\checkmark$ Deterring Terror. How Israel Confronts the Next Generation of Threats. English Translation of the Official Strategy of the Israel Defense Forces, "Belfer Center Special Report" August 2016 $<$ https://www.belfercenter.org/sites/default/files/files/publication/IDF\% 20doctrine\%20tr anslation\%20-\%20web\%20final2.pdf>

$\checkmark$ Dzisiów-Szuszczykiewicz A., „Trzęsienie ziemi” $w$ środowisku bezpieczeństwa Izraela, „Bezpieczeństwo Narodowe” 2011, nr 19, III

$\checkmark$ Kershner I., After Gaza Clash, Israel and Palestinians Fight With Video and Words, "The New York Times", 1.04.2018, <https://www.nytimes.com/2018/04/01/world/middleeast/ israel-gaza-fighting.html?module=inline $>$

$\checkmark$ Lerman E., Reasserting Israel's Deterrence in Gaza, The Jerusalem Institute for Strategy and Security, 11.12.2018, <https://jiss.org.il/en/lerman-reasserting-israels-deterrence-in-gaza/>

$\checkmark$ Newhard J. M., A Strategic Doctrine of Disproportionate Force For Decentralized Asymmetric Warfare, "Libertarian Papers" 2018, Vol. 10, No. 2,

<http://libertarianpapers.org/wp-content/uploads/2018/09/post/2018/09/ lp-10-2-3.pdf>

$\checkmark$ Orion A., The Gaza Spring Offensive: Hamas Hybrid Warfare Threat and Israel's Response, Friends of Israel Initiative, 29.06.2018, $<$ http://www.friendsofisraelinitiative.org/contents/uploads/papers/pdf/F OI_Paper48.pdf>

$\checkmark$ SIPRI, Data for all countries from 1988-2018 in constant (2017) USD, <https://www.sipri.org/databases/milex>

$\checkmark$ The World Bank, Population, total, $<$ https://data.worldbank.org/indicator/sp.pop.totl> 